\title{
Umbilicus in Different Languages
}

In English umbilicus is a common name which is Latin in origin, but the less common name which is German in origin is navel, (adj navel).

But the common term for ordinary people to call is "belly button"

- In Greek langue: omphalos

- In France: ombilical

- In Netherlands: navel, navelstreng, verbinding (figuurlijk)

- In Germany: nabelpunkt

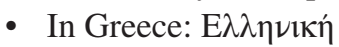

- In Italy: ombelicale

- Portugal: umbilical

- Russian: Русский пупочный, прочно соединенный, неотъемлемый, фала для связи астронавта или водолаза с кораблем, трубопровод наземного топливного питания ракеты

- Spanish: cordón

- Swedish: svenska

- Simplified Chinese: 中国话

- adj.: 脐带的, 脐状的, 脐的

- non: 脐带

- Traditional Chinese:

- 中國話

- adj.: 臍帶的, 臍狀的, 臍的

- $\mathrm{n} .:$ 臍帶

- Japanese: 日本語

- adj.: 臍の, へその近くの,へその

- n.: へその緒,つなぐもの

- Hebrew: נירובט, החפשמה תושנ adj. -

- Turkish: göbek bağ1 (funicle, navel cord, umbilical)

- Farsi: فان ماكدنوىي ,دننام فان ىكتففرورف

- Arabic: 